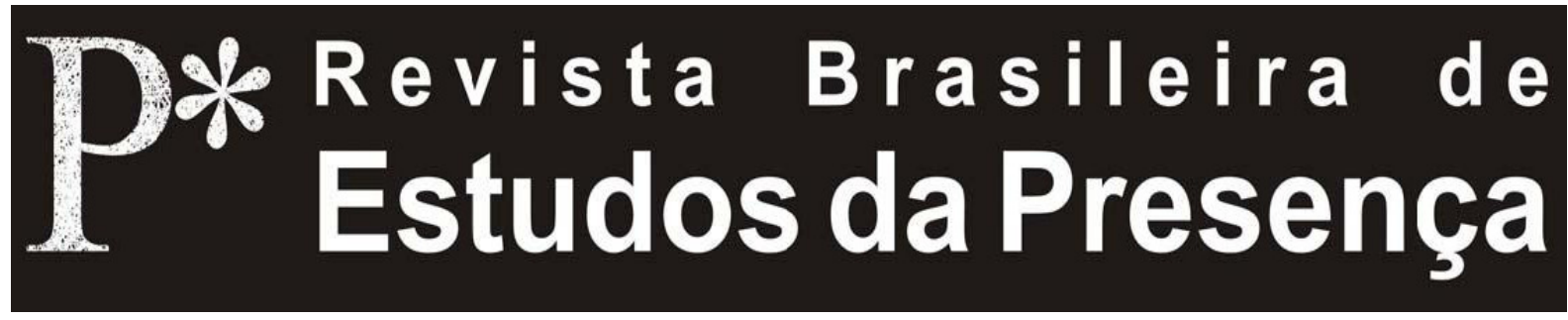

DOI - http://dx.doi.org/10.1590/2237-266024581

ISSN 2237-2660

\title{
Diálogos sobre a Narração -
É a nostalgia da fogueira, tenho certeza
}

Nara Waldemar Keiserman

Universidade Federal do Estado do Rio de Janeiro - UNIRIO, Rio de Janeiro, RJ, Brasil

RESUMO - Diálogos sobre a Narração - É a nostalgia da fogueira, tenho certeza - Reflexões sobre o teatro narrativo que tem na literatura de ficção sua base textual. Abordam-se aspectos como a passagem do livro para a cena, o uso de objetos, a espacialidade, a relação com o espectador, a composição gestual e o trabalho do ator, tendo como referência principal as experiências de encenação realizadas pela autora. $\mathrm{O}$ artigo mantém o formato dialógico, de acordo com sua matriz: entrevista realizada por Lígia Borges Matias como parte de sua pesquisa de Mestrado, em 2010, e que ocupa, assim, o papel de coautora do artigo.

Palavras-chave: Teatro Narrativo. Ator Narrador. Relação com Espectador. Teatralização. Gestualidade.

ABSTRACT - Dialogues on Narration - It's the nostalgia of the bonfire, I'm sure - Thoughts on narrative theater, with texts based on literary fiction. This text brings into focus aspects such as the creation of scenes based on books, the use of objects, spatiality, the relationship with the audience, the composition of gestures and acting. The author's stage experiences are the main reference for this paper. The keeps a dialogue format, according to its source: an interview which was part of the Master's degree research conducted by Ligia Borges Matias, the co-author of this article.

Keywords: Narrative Theater. Actor Narrator. Relationship with the Audience. Theatricality. Gesture.

RÉSUMÉ - Dialogues sur la Narration - C'est la nostalgie du feu, j'en suis sûr - Il s'agit d'une réflexion sur le théâtre narratif qui trouve dans la fiction littéraire son fondement textuel. Il traite des aspects tels que le passage du livre à la scène, l'utilisation d'objets, la spatialité, la relation avec le spectateur, la composition et le travail gestuel de l'acteur, ayant comme principale référence les expériences de mise en scène réalisées par l'auteure du présent article. Celui-ci conserve la forme dialogique présente à la source: l'interview réalisée par Ligia Borges Matias dans le cadre de sa recherche de Master en 2010. Cette dernière joue ainsi le rôle de co-auteure de l'article.

Mots-clés: Théâtre Narratif. Acteur Narrateur. Rapport au Spectateur. Théâtralité. Geste. 
Este artigo traz uma forma talvez pouco usual. São trechos de uma entrevista, realizada por Lígia Borges Matias, como parte da pesquisa para sua Dissertação intitulada Investigações acerca do uso da narrativa no teatro contemporâneo (Matias, 2010) em que a entrevistada assume a autoria do texto, acrescentando comentários e descrições mais explícitas às respostas dadas na ocasião, com o objetivo de explicitar o modo como tem trabalhado com o teatro narrativo. Essas falas novas aparecem em itálico. A entrevistadora exerce um papel de coautoria, por suas perguntas fornecerem a base temática do artigo, no entanto, como num programa de televisão conhecido, elimina-se a pergunta, implícita nas respostas, sendo que estas mantém a marca da oralidade, liberando a autora para um certo achismo - com o perdão da má palavra. As outras operações realizadas no original, que se encontra como um dos Anexos da citada Dissertação, não publicada, foi a reorganização sequencial dos assuntos abordados e a inclusão de notas e de referências bibliográficas. A entrevista foi realizada durante o V Congresso ABRACE, em 31 de outubro de 2008, na UFMG.

Os espetáculos aqui referidos: Ionesco! com trechos das peças Jeux de massacre, A lição e Amadeo ou como se livrar da coisa ${ }^{1}$, História de amor, conto de Heiner Müller e Nós somos os propositores, sobre as cartas trocadas entre Lygia Clark e Hélio Oiticica foram produzidos no contexto da pesquisa institucional $O$ Ator rapsodo: pesquisa de procedimentos para uma linguagem gestual, desenvolvida na Universidade Federal do Estado do Rio de Janeiro (UNIRIO) desde 1997, com alunos bolsistas de Iniciação Científica ${ }^{2}$ e colocados em cartaz em teatros públicos - Espaço Cultural Municipal Sérgio Porto, o primeiro, em 2003 e Espaço Rogério Cardoso, na Casa de Cultura Laura Alvim, o segundo, em 2006, ambos no Rio de Janeiro. (eu) Caio, 2004, com textos de e sobre Caio Fernando Abreu, O narrador, 2005, contos de Anton Tchecov, João Alphonsus, Carlos Drummond de Andrade e outros e $A$ incrivel bateria, 2008, com contos de João do Rio, Marques Rebelo, Luiz Antonio e outros foram produzidos pelo grupo Atores Rapsodos, sendo que estes estão inseridos no merca- 
do profissional: cumprem temporadas mais ou menos longas em espaços teatrais, contam com patrocínios via prêmios de editais públicos, os atores são profissionais, em sua maioria ex-bolsistas da mesma pesquisa. Nos dois contextos, os atores estão investidos da autoria, instalada sobre a ideia de partilhamento criador.

\section{Dois Inícios}

Iniciei o contato com o teatro narrativo em 1975, com a montagem de A Salamanca do Jarau, de João Simões Lopes Neto. A proposta veio de um grande amigo que tenho até hoje, que é o Luis Artur Nunes. Foi ele quem teve a ideia de montarmos esse espetáculo, que ele mesmo dirigiu. É uma lenda gauchesca, narrada inteirinha em primeira pessoa e por um mesmo ator; era a lenda na íntegra e eu, ali, fiz inicialmente assistência de direção, eu estava grávida da minha segunda filha, então eu não podia trabalhar como atriz, porque ela ia nascer durante a temporada. Fiz a assistência de direção, trabalhando especialmente as partes corais, num grupo de atores que vivificava, apresentava os acontecimentos narrados. Esse ator era o José de Abreu, ele entrava e saía da ação; ele tinha um espaço narrativo fora da área da ação, mas, eventualmente, entrava participando desses momentos vivificados, presentificados da narrativa. Depois, numa segunda temporada, eu entrei como atriz e fizemos apresentações em São Paulo, no Theatro Municipal. Tenho de lá uma lembrança muito especial, que foi quando o Antunes Filho foi ao camarim e disse: 'Vocês descobriram a saída para o teatro'. Isso foi em 76, no primeiro semestre de 76, eu acho. Depois a gente começou a fazer teatro-dança e enveredamos por outros caminhos e só voltei a fazer um teatro narrativo no Rio de Janeiro, em 1982, com a encenação de contos do livro Morangos mofados, do Caio Fernando Abreu.

Essa montagem foi com um elenco formado por um grupo de alunos da CAL - Casa das Artes de Laranjeiras. A partir daí, tenho mantido a preferência determinada pela cena em que o diálogo não é o único modo de enunciação verbal. Ao poder usufruir de todos os gêneros literários para ocupar o 
palco, o mundo se expande, a cena transborda e todos podemos ser mais felizes. Eu acho.

\section{Adaptação, Transcrição, Teatralização}

Em Morangos mofados, trabalhei direto do livro para a cena, não tem uma adaptação em papel, não lembro como os atores faziam, mas não existe essa versão em papel, só existe o livro. Mas naquela época eu ainda fazia uma espécie de adaptação, não no sentido de transformar o texto em diálogo. Alguns elementos descritivos eu transformava em ação ou intenção, mas não houve absolutamente uma transformação em diálogo. Mantinha o 'ele disse', 'ela disse', mas, por exemplo, se o conto dizia que a personagem estava triste, ao invés de dizer que a personagem estava triste, a atriz se encarregava da fisicalização do estado de tristeza, coisas assim. Eu tive também, naquela ocasião, uma experiência interessante com um dos contos $O$ dia em que Urano encontrou Saturno, que conta a história de quatro amigos dentro de uma casa. A gente foi compondo pela improvisação, lia o conto, os atores faziam, fomos montando assim. Um dia o Caio falou: 'Deixa eu adaptar pra vocês' e ele trouxe a adaptação; eu li e não gostei, fiquei com vergonha de dizer, mas ele, num insight, falou 'O de vocês é muito melhor' e rasgou na minha frente o que ele tinha feito. Esse episódio me fez pensar na força do que é feito em ação, pelo viés da compreensão que passa por uma corporeidade efetiva. Sempre dá certo.

Tenho adotado diferentes procedimentos nessa passagem do livro para a cena e cada um determinado tanto pelo material literário escolhido - tendo a dizer 'premiado' - quanto pela linguagem de cena pretendida. Em todos eles, a palavra do autor do texto tem importância capital - não fosse assim, escolheria outro texto ou nenhum.

\section{Os Objetos, o Figurino, o Corpo}

Eu tenho medo das coisas. Há pouco tempo eu fiz uma peça realista, como atriz ${ }^{3}$. Teve um dia do ensaio em que o diretor riscou o chão e disse: 'Aqui é a parede, aqui é a porta 
que dá pra cozinha...'. Eu tive um acesso de riso. Disse 'O quê? Como é que é?' [o diretor] 'Aqui vai pra cozinha' [ela rindo] 'Vai pra onde?' (risos) e eu: 'Vai ter tudo?', [ele] 'Claro, você não entendeu, é realismo'. Eu digo 'Ok, é realista na composição dos personagens, é verossímil, mas ter tudo?'. Para mim isso é inadmissível, eu não posso conceber um teatro assim. Tenho sempre a sensação que as coisas afastam o olhar do espectador para o que não é tão importante e, por isso, eu fui sempre trabalhando em cima do corpo do ator; eu acredito que o corpo do ator dá conta de tudo o que é necessário, mesmo. Só não trabalho com a nudez porque ela se instaura como uma categoria específica, porque eu acho que nem a roupa precisava, mas, como a não roupa já é outra coisa, eu sou obrigada a pedir que todos se vistam. Eu reli Meierhold e estou com o firme propósito de, nesse trabalho de pesquisa que estou fazendo agora ${ }^{4}$, adotar o macacão. Tenho pedido aos atores, quando vamos apresentar a pesquisa, que usem roupa de trabalho. Só que a roupa de trabalho desses meninos é muito charmosa; por mais que eles venham de preto e a roupa seja rasgadinha. Porque tudo vira signo, então se alguém colocou a camiseta do lado do avesso isso significa, se a blusa está rasgadinha isso significa... Então estou pensando em um figurino que seja igual à roupa de trabalho, não a roupa de o ator fazer as suas performances, é diferente, estou realmente decidida a adotar o macacão. Então quando eu digo 'o despojamento' e 'eu tenho medo das coisas', e na verdade foi isso o que tu me perguntaste: como é que os objetos entram... Como eu tenho paixão pelos objetos eles entram com muito cuidado. Eu fiz um espetáculo como atriz e era a narradora ${ }^{5}$, o diretor dizia 'Aqui vai ter um painel com cartazes, que você vai...' e não chegava o tal do painel. Chegou no ensaio geral, eu disse 'Pode jogar fora isso porque eu não vou usar', e disse pra ele: 'Tu sabes como é minha relação com o objeto, eu me nego a usar em cena amanhã uma coisa que chegou hoje'. Foi recolhido o painel, não sei onde foi parar, mas não entrou em cena. Eu tenho paixão pelos objetos, então cada objeto, quando entra, ele tem um valor como um parceiro de cena. Quando eu trabalho com os alunos com objetos eu digo isso 'É uma cena de dupla, por 
acaso um é um objeto'. Nesse último espetáculo que dirigi, que se chamava Incrível Bateria, eram contos de carnaval, músicas de carnaval o tempo todo, com todas as movimentações dos atores sendo dançadas; eles dançavam uma dança-samba, sambavam do início ao fim do espetáculo enquanto iam narrando e vivificando as histórias. Foi engraçado aquilo, porque não tinha cadeira - em nenhum momento me passou pela cabeça que algum personagem ia precisar sentar. Eles não sentam! Eles estão sambando, como é que vão sentar? E veio daí o não sentar. No História de amor eu fiz uma introdução para a peça: eles começam descascando laranjas, comendo laranjas e tiram da boca, põem na boca do outro, chupam a mesma laranja, contando essas histórias que eu tirei do Círculo dos mentirosos, o livro do Carrière. Contam histórias um para o outro, sentadinhos no chão. Então nós temos esses objetos ali: uma tábua, uma bacia com laranjas e uma faca. É uma presença fantástica. Depois, na hora em que ela conta que ele quer que ela tire o filho, ela corta aquelas laranjas furiosa. Conta que ele foi embora e ela ficou esperando por ele... aí ela fica em silêncio, cortando laranjas, dá uma sensação de passagem de tempo, parece que ela ficou dois meses cortando laranjas, esperando ansiosa, nervosa, ele chegar pra comerem juntos. Eu não me lembro como começou, não lembro quem trouxe as laranjas, realmente, mas assim: 'Tem laranjas aqui / aqui tu cortas mais ligeiro / faz isso / faz aquilo' eu que fui dizendo, porque eu vou enxergando, né? Se eu não enxergo, não dá para fazer, não consigo fazer, eu preciso enxergar. No $O$ narrador a gente tinha o conto Sapatinhos vermelhos, do Andersen, que vinha logo antes do Sapatinhos vermelhos do Caio Fernando Abreu, e foi uma coisa também que eu enxerguei, na hora em que a menina fica desesperada, ela não consegue tirar os sapatinhos, a gente fez assim. Os atores tinham garfos espetados em rabanetes e faziam uma dancinha, citando Chaplin ${ }^{6}$. Era linda, linda, linda essa cena, os quatro atores atrás da mesa a gente tinha uma mesa - faziam vários passos. Esses passos a gente inventou e só depois os atores reproduziam com os rabanetes. O narrador tem objetos, eles comem durante a peça em quase todas as cenas, e tem uma cena, $O$ guardador de 
patos, de Hermann Sudermann, em que a personagem, uma menina, seduz o menino pela comida. Na hora em que os atores abrem aquilo e são doces super apetitosos, a plateia geme. E tem outro conto que é $A$ galinha cega, de João Alphonsus, em que a atriz, que faz o papel da dona da galinha, come uma galinha assada também em cena e a plateia delirava também. Aquilo era uma diversão.

No item 6, sobre a relação com o espectador, está explicitado o papel dos sentidos nessa montagem.

\section{O Ponto de Partida}

É diferente para cada trabalho. Por exemplo, o que eu estou fazendo agora ${ }^{7}$, com essa intenção de fazer um teatro - tenho medo da palavra - político. Estamos, [os bolsistas e $e u$ ], chamando de político porque [o trabalho] pretende trazer para o espectador uma reflexão sobre a realidade, sobre os fatos econômicos, sociais, principalmente sociais; pretende proporcionar uma reflexão, fazer a pessoa se pensar como ser social e é isso que nós estamos chamando de teatro político. Então, nós ficamos lendo durante uns três meses, lendo várias coisas até bem diferentes entre si. A gente começou pelo teatro. Quando nós optamos, houve um 'Vamos fazer teatro político? É isso? Então vamos ler Piscator'. Primeira coisa: 'Vocês vão ler o Teatro político do Piscator, vão ler o livro Teatro de militância da Silvana Garcia, vamos ver tudo o que a gente tem de Brecht em português', foi essa a primeira coisa que a gente fez. E aí, outras coisas. Já vínhamos lendo as crônicas do Fausto Wolf - morreu agora, um colunista, cronista, o último comunista - que ele publicava em uma coluna diária no Jornal do Brasil, muito contundente. Eu levava aquilo para a gente discutir e outras coisas avizinhadas. Eles trouxeram Eduardo Galeano e, a partir dele, a gente tirou temas, que serviram de eixos para improvisações e também para a construção de pequenos eventos cênicos, que os atores preparavam e mostravam. Muitos temas foram se desdobrando em outros e fomos discutindo várias outras coisas. É isso, em cada trabalho a coisa vem de maneira diferente. Pessoalmente, sou muito movida pela música, muito, mas quando eu vou pensar 
em um trabalho, eu penso em um texto. Eu ainda tenho esse vício. Porque quando a gente pensa 'Ah, vamos nos livrar do texto', eu fico pensando 'Por que, hein? Por que mesmo a gente tem que se livrar do texto? Não quero, eu adoro a palavra' e a literatura é uma coisa maravilhosa. Fui atraída pelo literário porque o mundo fica muito grande, é isso. E esse é inclusive um traço épico. E então vêm as escolhas, os textos que me movem. E esse 'movem' é literal, que me tiram da cadeira, que me fazem agir, me movimentar. Então o processo vem, normalmente, de um texto, aí ele é ampliado, às vezes articulado claramente com outros desejos, como no Ionesco!. Havia ali uma proposta concreta: 'Vamos trabalhar sobre objetos' e essa é uma coisa que eu ainda trabalho numa disciplina, mas sempre é uma coisa um pouco limitada, com atores pouco experientes, em dois meses de aula uma vez por semana. $\mathrm{Na}$ pesquisa, eu pude então ficar durante um ano com atores mais experientes, experimentando.

O ponto que nos move é sempre acordado entre os pesquisadores - alunos bolsistas e coordenadora. Algumas vezes, me dou ao luxo de iniciar uma nova etapa sem saber exatamente o que vai ser trabalhado. É o próprio trabalho que se apresenta, numa espécie de 'agora eu!' Neste momento, 2011, estamos dando início a uma etapa bastante distinta da Pesquisa. Nomeada de Corpo Infinito, estamos investigando as relações entre a Susksma Vyayama Yoga e elementos da Leitura Corporal, de Nereida Fontes Vilela, que interessam ao trabalho do ator. Intuímos ai a possibilidade de uma abordagem da criação de cena através da mobilização consciente dos Corpos Físico, Mental, Emocional e Etérico ${ }^{8}$ (Vilela; Santos, 2010).

\section{Ilustrar, Presentificar, Vivificar, Compor}

Para mim, presentificar se refere à ação. Vivificar também. Meierhold foi o primeiro a usar a expressão 'partitura' para o trabalho do ator, talvez por sua ligação com a música. Meierhold diz que trabalha melhor com os atores que amam a música. É interessante, porque os músicos querem se livrar da partitura, porque ela é feita de barras, linhas e barras, e aí eu 
tenho evitado a expressão 'partitura' tentando substituir por uma ideia de 'sequência de ações'. Ações sequenciadas, porque 'partitura' parece realmente algo que não pode mudar, mas quando você pensa em 'sequência de ação' você pode mudar a sequência, pode alterar a ordem, dá uma sensação de mais liberdade. E a 'composição' é o resultado, é a somatória das sequências, você vai compondo. Na minha defesa do doutorado, em dezembro de $2004^{9}$, a Ingrid Koudela ${ }^{10}$ fez uma ressalva a minha tese por conta do uso desse verbo 'ilustrar' (Ela tinha toda razão). Passei a associar e compreender 'ilustrar' como o que, antigamente, a gente chamava de dramatizar. Muito antigamente, nunca mais ouvi falar nessa palavra, falava-se em 'dramatização', como nos primórdios do teatro na escola em que colocavam as criancinhas para dramatizar. Então era assim: contavam a história da Chapeuzinho Vermelho e as crianças levantavam e dramatizavam a história da Chapeuzinho Vermelho. E o 'ilustrar' talvez traga um pouco essa conotação do 'dramatizar', do fazer igual, tem uma ideia de cópia, de formalização empobrecida. Percebo um uso pejorativo. A gente diz 'Ah, é simplesmente ilustrativo'. Mas às vezes isso é bom. Eu sempre trabalhei tendo essa fricção, o embate entre as duas camadas de expressão, oral e gestual, acho mais divertido pra quem vê. É mais difícil para o ator fazer, portanto melhor, pra mim o mais difícil é sempre melhor porque é mais prazeroso e porque faz crescer. Mas o Luis Artur trabalha, digamos, com uma linha mais ilustrativa. Então acho que, às vezes, ele ficava meio incomodado com a minha insistência nesse embate e me dizia que, na intenção, a ilustração serve como um sublinhar. Quando você diz uma coisa e faz a mesma, o fazer vem sublinhar aquilo que é dito, então muitas vezes o ilustrativo é desejável nesse mesmo sentido. O que não pode é se tornar empobrecedor, porque o 'lance' todo é uma aposta na inteligência do espectador.

A referência ao Prof. Dr. Luis Artur Nunes se dá por ele ter sido o diretor dos espetáculos do Núcleo Carioca de Teatro, grupo que fundamos em 1992, juntamente com Maria Esmeralda Forte, Ivo Fernandes e Shimon Nahmias, com um investimento determinado no teatro narrativo ${ }^{11}$. Foi também 
meu orientador no Doutorado realizado no PPGAC-UNIRIO, 2004. Ultimamente, tenho trabalhado a gestualidade partindo do 'o que isso te faz fazer?' sendo que 'isso' pode ser o texto como palavra, como sentido, como sensação; o 'isso' pode ser a música, o objeto, a presença do outro ator.

Na relação texto versus movimento, tivemos uma experiência ímpar. Estávamos com História de amor, quando fomos convidados para participar de um encontro entre estudiosos de Lacan, que naquele evento estavam discutindo as questões relativas ao Amor. Era numa livraria. Ao chegarmos lá, vimos que não havia um mínimo de espaço para a representação. Então, decidimos fazer - se é que posso dizer assim - com os dois atores sentados a uma pequena mesa, de frente um para o outro, dizendo as palavras do conto. Ambos (Karen Coelho e Iury Salustiano) tinham as palavras impregnadas não só de sentidos e intenções, como de imagens e movimentos, com suas pulsões físicas, tonicidade, equilíbrios, que naquela circunstância tinham uma espacialidade extremamente restrita de manifestação, além das palavras. O que aconteceu foi o que se pode imaginar: a potencialização das palavras conferiu a elas uma força que os atores nunca haviam experimentado, acrescentando ainda mais uma camada de tensionamentos $e$ de sentidos. Seus olhos faiscavam, seus rostos quase se contorciam até o momento em que, numa explosão, o ator levantou-se, colocando-se atrás da atriz para permitir aos dois o contato corporal que ansiavam até o insuportável.

\section{O Espectador}

Acho que tudo começa por 'Para quem a gente trabalha? Com quem a gente quer falar?'. Quando a gente fala em contar histórias, está ali pressuposto o ouvinte. Está bem junto com o ato de narrar, o de ouvir, então 'Quem é? Com quem estou falando?', acho que essa pergunta tem que estar presente o tempo inteiro. Como eu disse antes, tem essa aposta na inteligência do espectador. Tem um público para quem a gente pode falar e que está disposto a um investimento intelectivo e, principalmente, a um investimento que passa pela via sensorial - aí passa por um gosto meu. Assim: quando eu tenho 
alunos $^{12}$ do primeiro período, eu trabalho uma coisa que chamo - chamo não, o programa já veio assim - de: 'os sentidos e sua relação com o movimento', eu já fazia sem dar esse nome. No início, eram duas semanas de trabalho e hoje eu estou no terceiro mês de aula e acabamos de acabar essa unidade do programa, então poderia fazer o semestre inteiro 'os sentidos e sua relação com o movimento'. Então, eu comecei a desejar um espetáculo em que pudesse proporcionar para o espectador essa mesma coisa que eu proporciono para os meus alunos; escrevi o projeto [para encenar $O$ narrador], ganhamos o edital, mas eu não consegui realizar o projeto que escrevi. Não consegui. Precisaria de muito mais tempo de ensaio e fomos atropelados por coisas concretas, como o surgimento de uma pauta para dali a três meses que não podíamos perder. É um projeto que, como não foi realizado do jeito que está escrito, posso retomar a qualquer momento, porque eu não fiz aquilo. A ideia era mais ou menos assim: a gente faria uma seleção de contos em que um dos sentidos fosse mote e cada ator escolheria, pelo seu sentido (tato, visão etc.) predileto, qual conto fazer e levantar ele próprio. Por exemplo: A Natasha [Corbelino] escolheu o conto Sapatinhos Vermelhos, do Caio Fernando Abreu e, digamos que o sentido predileto dela fosse o olfato, então ela iria começar a trabalhar o conto estando com o olfato absolutamente vivificado. Isso a colocaria em um estado para resolver o que fazer com aquele conto. Todos os contos que escolhemos tinham como ponto central um dos sentidos. Eram dois contos para cada um dos cinco sentidos e pequenas histórias de ligação falando dos sentidos, que eu tinha lido num livro do Jean-Claude Carrière, chamado Círculo dos mentirosos - que é uma coisa maravilhosa, já usei várias vezes. Fazíamos assim: distribuíamos para os espectadores uns saquinhos com cinco objetos que despertavam os sentidos e dávamos um tempo para eles viverem uma experiência sensorial e, a partir dessa experiência sensorial, cada espectador votava em um dos sentidos. Os dois sentidos vencedores da noite eram os contos que a gente fazia. A partir daí, passa a prevalecer a visualidade.

Sabemos que a visualidade ativa a memória sensorial. Por isso é que a plateia podia deleitar seu paladar ao ver 
os atores comendo em cena. Tenho grande admiração pelo trabalho sobre um teatro dos sentidos.

\section{O Acaso/a Improvisação: o ator e a plateia}

A construção usada em $O$ narrador fazia termos um espetáculo diferente a cada apresentação. Era divertido ver o iluminador reprogramando a mesa e o operador de som preparando o roteiro. Essa experiência com o acaso era bastante radical em (eu)Caio. Acho maravilhoso para os atores terem que lidar com o acaso. Primeiro, porque os coloca sempre em um estado de risco, de insegurança e risco, e isso deixa a pessoa completamente viva. Acho que esse é o grande barato. E a plateia sabe que eles estão nesse estado de risco. Para os dois trabalhos, (eu)Caio e $O$ narrador, escrevi uma espécie de prólogo, em que se explicam as regras do jogo. Tem que explicar as regras do jogo. Todo mundo quer ver o circo pegar fogo, a pessoa quer ver o ator errar. É diversão. No (eu)Caio, principalmente nos momentos em que os atores contavam histórias pessoais, eu acho que muita gente tinha vontade de levantar e contar. No Narrador, quando a gente estreou, sim, depois a gente abriu mão disso. Nós fizemos seis sessões no Espaço SESC, em Copacabana, então tivemos seis atores convidados; a gente deu para eles um livro dos melhores contos do João do Rio e cada um escolheu uma história para contar, que nós não sabíamos qual era; no final, a gente convidava alguém da plateia que quisesse contar uma história. Sempre tinha. Mas, depois que entrou em cartaz em teatro convencional, abrimos mão disso.

Nestes dois trabalhos, os atores recebiam o público como se recebe convidados em casa para uma festa. Em (eu)Caio, os atores serviam refrigerantes, salgadinhos, música tocando, social. A passagem deste clima para o início da peça era muito sutil, nenhuma grande mudança de luz, salgadinhos ainda sendo servidos e uma das atrizes iniciava o texto do prólogo, em que se pedia aos espectadores para sortearem os contos, escolherem os personagens, um jogo. Chamamos mesmo de (eu)Caio-jogo teatral. Na performance, resultante do trabalho sobre as cartas trocadas entre Lygia Clark e Hélio Oiti- 
cica, que chamamos de Nós somos os propositores, todas as ações se passavam sobre uma toalha em que estavam servidas comidas e bebidas, como uma grande toalha de piquenique. Os atores convidavam os espectadores a se acomodarem ao redor da toalha e serviam, diretamente em sua boca - não havia talheres - quitutes que nós mesmos preparávamos. Em Ionesco! eu mesma fazia esse papel de receber o público. Tinha uma sensação muito clara de que 'fizemos para vocês, que bom que vieram'. Gosto da comunhão. Apesar de utilizar em alguns trabalhos estruturas fragmentadas, que propõem aos espectadores algum grau de decifração, e esta será sempre particular, almejo ainda aquela plateia que se podia chamar de assembleia. Ainda me debato, insatisfeita e indecisa, na utilização dos termos 'público, plateia, espectadores'. Gosto mesmo é de 'convidados'.

\section{O Espaço, a Luz}

Em geral, começo tendo certeza que palco italiano não é! (risos) É a primeira coisa que sei e depois eu vou ver, mas quase em seguida eu enxergo. Ionesco! desde o começo eu enxergava de comprido, era mais um trilho; na verdade eu enxergava uma mesa, porque eu enxergava aquela coisa de mosteiro medieval, uma mesona que definiria o palco-plateia. Não deu pra fazer, virou um trilho no chão que significava a rua, mas eu sempre enxerguei de comprido. A incrivel bateria, a gente transformou o espaço: a pessoa entra e parece que está entrando num baile de clube, com mesas, decoração de carnaval e os únicos adereços são máscaras de carnaval que os atores usam, eles não têm nada na mão. $O$ narrador era feito bem pertinho, era uma sala, a plateia bem pertinho, porque a outra coisa que eu vejo nisso é realmente uma nostalgia da lareira, da fogueira. É a nostalgia da fogueira, tenho certeza. Nas últimas coisas que fiz, o público fica pelo menos parcialmente iluminado. Na Incrivel bateria não tinha como, a luz batia em todo mundo, no Narrador também, no prólogo iluminava-se todo o público, não tinha mudança de luz desde o terceiro sinal até o início da peça. 
A verdade é que não enxergo a luz. Tenho trabalhado sempre com o Demetrio Nicolau como iluminador-é ele também quem faz as trilhas - e ele reclama que eu não considero a luz quando marco a cena. É verdade. Tenho um 'problema' com a ideia de 'criar um clima'. Não gosto de truques, nem de 'provocar um efeito'. E sempre acho que a luz vai diminuir a visibilidade, vai esconder ou camuflar movimentos tão exaustivamente trabalhados, atitudes corporais tão milimetricamente desenhadas. Mas me rendo. Tenho optado por uma luz que recorta o espaço, que imprime andamentos.

\section{Ainda Stanislavski}

$\mathrm{O}$ ator-narrador é um ator e não propriamente o que se tem chamado de contador de histórias. A narração é uma especialidade, é uma especialização. É como se fosse assim: 'todo mundo tem que passar por Stanislavski, todo mundo tem que fazer balé clássico'. Então você tem que fazer Stanislavski para depois narrar. O que eu vejo do Stanislavski... É bacana porque, quando a gente começou a trabalhar História de amor, nós não sabíamos ainda como seria; a história é contada na terceira pessoa e a gente manteve 'ele', 'ela'. No começo, não sabíamos se os atores eram ou não eram os personagens da história. Eu disse 'A gente não precisa resolver agora, vamos ver como vocês vão estabelecendo essa ficção' e eles um dia me confessaram 'Eu sou' e eu disse 'Ok' - apesar de falarem na terceira pessoa e no passado, a atitude deles era totalmente de presentificação. Então eu acho que o ponto é o lugar: 'Eu estou no lugar do personagem?', eu acho que o ponto é o 'lugar', é distância. Sempre há a distância, mas o Stanislavski tem várias coisas que são preciosas como, por exemplo, o grau de verossimilhança, de fé cênica - principalmente fé cênica - de compreensão das circunstâncias dadas... tem vários elementos do Stanislavski que não há como não reconhecer e apostar. Porque o que ele fez de melhor foi a análise do que está acontecendo ali; não tem propriamente uma invenção, mas ele conseguiu perceber o que é o fenômeno teatral do ponto de vista do ator e, com isso, tornou acessível para todo mundo aquilo que só os geniais conseguiam. Nós nos distanciamos 
de Stanislavski por causa do espaço que a gente abre para o comentário e para a opinião pessoal. Por exemplo, quando a gente vê uma peça 'realistona' - que é muito boa quando é bem feita, mas é cada vez mais raro de ver - aquilo é dado como imutável, você aceita aquilo assim. Se você for ver de novo e o ator tiver mudado, você vai ficar indignado, porque ele está te ludibriando; você compra aquilo como 'assim é'. E no nosso teatro isso não existe, é como no Brecht, o espectador tem que ver 'assim' e também 'assim', ao mesmo tempo ele tem que ser capaz de pensar que poderia não ser assim, isso que eu acho bacana. Então no 'vir à frente' está contido o 'ir pra trás', e a gente tem que achar jeitos para que isso se apresente.

Cada vez mais, vejo a decisão como fator fundamental e que deve ser evidenciado na elaboração do que está sendo mostrado/visto. Acho importante que se assuma o ato especial, a bolha, o recorte da realidade "real" que o teatro - em que instância performativa for-instala. Nessa fricção entre realidade e ficção que algumas experiências propõem, não vejo a menor graça se a intervenção do artista estiver 'disfarçada'. Há que haver opções e viva o livre arbítrio!

\section{Ler e Imaginar; Ver e Narrar}

Quando montei Morangos mofados, uma coisa que eu dizia para os atores era que eu pretendia que o espectador tivesse a mesma experiência que eu, que nós tivemos como leitores, mas já ando 'meio assim' com isso. Porque acho que o espetáculo tem o compromisso de oferecer uma coisa a mais, senão dá o livro para a pessoa ler, coloca uma musiquinha de fundo e vamos todos embora. Qual a vantagem, então? O espetáculo tem que oferecer uma coisa a mais e esse a mais é aquilo que você enxerga, é o seu comentário, é a sua opinião, que o espectador pode partilhar ou não. Por isso que tem que ter, o espetáculo tem que dar espaço para o 'ou não' e tudo deve ser mostrado de uma forma que pressuponha o seu contrário. Eu acho que no História de amor é muito claro como as coisas são claramente opções da cena: nunca poderia ter acontecido daquele jeito porque o que os atores fazem, a sua gestualidade e movimentação é totalmente deslocada de uma 
realidade, nunca poderia ter acontecido daquele jeito, então 'eles escolheram fazer assim, poderiam ter escolhido fazer de outro jeito'. Há uma nítida e assumida construção de linguagem, de teatralidade. Outra coisa que é própria da narrativa, é que o livro você para, pensa, lê de novo, e a cena está andando. Há um tempo próprio para o espectador 'ver' o que está sendo narrado. Se eu não 'tô' enxergando, digo: 'Pode parar'. 'Pode parar, não estou enxergando nada!'. Eu tenho certeza, já experienciei isso, se eu, como observadora, orientadora, diretora, espectador privilegiado, não estou enxergando nada, o ator também não está. Ele que tem que se dar o tempo de enxergar; se ele não está enxergando, ninguém mais enxerga e aí é Stanislavski de novo. É um tempo que se mantém na encenação. Não tem nada de ir sintetizando os tempos, precisa no tempo da encenação, mas isso já é diferente no Stanislavski em que os tempos vão sendo sintetizados.

Sobre a visão. Há alguns atores com quem tenho trabalhado, que eu posso ver quando estão vendo, no processo dos ensaios. O olhar se modifica. Alguns precisam parar de agir, porque a visão é tão potente que os paralisa momentaneamente. É preciso digerir, 'metabolizar', diria meu amigo Renato Icarahy ${ }^{13}$, compreender para então dar corpo e voz àquilo tudo. Outros vão enxergando enquanto fazem, só enxergam em movimento; é como se o espaço oferecesse o buraco em que o ator deve penetrar para ali dar corpo à imagem e o ator simplesmente vai - e faz. Quando dirijo, muitas vezes preciso levantar e fazer, para compreender melhor o que estou enxergando. Acho que isso é vício de atriz.

\section{Personagem Narrador}

Eu acho que o narrador é um personagem, porque assim - aí teria uma discussão de o que é personagem - eu acho que no momento em que você subiu no banquinho você é um personagem. O teatro começou assim, né? Alguém pegou um banquinho, uma caixa, uma coisinha, subiu em cima e começou a falar. Está feita a coisa. Então você fez isso, é personagem. Mesmo que ele tenha o 'meu' corpo, a 'minha' voz, mesmo que não tenha nenhuma configuração especial, especialmente 
criada vamos dizer, ainda assim, para mim, é um personagem. Então, por exemplo, nessas historietas que existiam dentro da peça $O$ narrador, muito curtas, havia uma personalidade narradora. Cada ator-narrador tem, é quase como um palhaço. Tem uma personalidade narradora, então é um personagem. É uma personalidade narradora que contempla a sua opinião, seu ponto de vista, seu modo de enunciação, o modo como você trabalha as imagens.

Exemplo muito simples: estive como atriz nas duas montagens de A vida como ela é, as crônicas de Nelson Rodrigues, realização do Núcleo Carioca de Teatro, direção de Luiz Arthur Nunes, em 1992 e 2002. A primeira crônica do espetáculo, O desgraçado, tem um coro de narradores, de composição individualizada. O temperamento narrativo que imprimi em 2002 tem traços bastante diversos do anterior, sem que isso modifique em nada o desenho e o conjunto.

Gostaria de concluir com uma das pequenas/grandes histórias do livro do Carrière (2004, p. 414):

\footnotetext{
Diante do oceano

Uma história persa muito antiga mostra o narrador como um homem isolado, de pé sobre um rochedo diante do oceano. Ele conta, sem parar, história atrás de história, mal fazendo uma pausa para beber, de vez em quando, um copo d'água.

O oceano, tranquilo, o escuta fascinado.

E o autor anônimo acrescenta:

- Se um dia o contador se cala, ou se fazem com que ele se cale, ninguém pode dizer o que fará o oceano.
} 


\section{Notas}

${ }^{1}$ Estas peças foram consultadas em versões mimeografadas disponíveis no Banco de Peças da Biblioteca do Centro de Letras e Artes da UNIRIO, em traduções de Marcella Mortara, a primeira e de Luis de Lima, as demais.

${ }^{2}$ De 1997 a 2011, os bolsistas PIBIC ou IC: Ângela Blazo, José Karini Júnior, Catarina Alfarone, Vivian Duarte, Natasha Corbelino, Helena Borschiver, Rodrigo Faria Dias, Natali Malena Trunckle de Oliveira, Andrea Santiago, Karen Coelho, Iury Salustiano, Mariana Mordente, Caito Guimaraens, Renata Sampaio e Douglas Resende.

${ }^{3}$ Qual foi teu sonho na vida, meu bem? de Wilson Sayão, direção de Demetrio Nicolau, 2004.

${ }^{4}$ Naquele momento, com os bolsistas de Iniciação Científica Carlos Guimaraens Bueno da Silva e Mariana Volfzon Mordente, alunos do curso de Bacharelado em Artes Cênicas - Habilitação Interpretação, da Escola de Teatro da UNIRIO, trabalhávamos sobre um material textual e de gestualidade que resultou no que chamamos de peça-debate Afinal sou apenas um ator: quando o teatro e a política se encontram, baseado em Mefisto, de Klauss Mann, com textos de Piscator, Meierhold e Brecht.

${ }^{5}$ Forró da revolução popular, textos de Peter Weiss, Henri Ghéon e outros, com direção de Demetrio Nicolau, realização da Companhia pop de teatro clássico, em cujas montagens faço Direção de Movimento ou Preparação Corporal.

${ }^{6}$ A cena é do filme Em busca do ouro, de 1925, em que Carlitos manipula com garfos dois pãezinhos, criando uma imagem de pernas e pés que dançam.

${ }^{7}$ Trabalho referido na nota n. 2.

${ }^{8}$ Segundo Nereida Fontes Vilela e João Celso dos Santos, o etérico é "[...] um corpo que olha tanto para o inconsciente quanto para o consciente. [...] No plano sutil, o Corpo Etérico transporta e transmite os impulsos-mensagens, que são códigos que suscitam e impulsionam a inspiração, o desejo e a vontade - forças geradoras do movimento" (Vilela; Santos, 2010, p. 25).

${ }^{9}$ Caminho pedagógico para a formação do ator narrador, orientador Luis Artur Nunes, PPGAC-UNIRIO, 2004.

${ }^{10}$ Ingrid Dormien Koudela - Graduada em Artes Cênicas pela ECA/USP (1971) com Mestrado, Doutorado e Livre Docência pela ECA/USP. Atualmente é pesquisadora com Bolsa de Produtividade de Pesquisa pelo CNPq. Autora de Jogos Teatrais (Perspectiva, 1984); Texto e Jogo (Perspectiva, 1996); Brecht: um jogo de aprendizagem (Perspectiva, 1991); Brecht na Pós-Modernidade (Perspectiva, 2001); Heiner Müller: o espanto no teatro (Perspectiva, 2003); Büchner: na pena e na cena (Perspectiva, 2004) entre outros. Introdutora do sistema de Jogos Teatrais de Viola Spolin no Brasil, é tradutora de Improvisação para o Teatro (Perspectiva, 1983) e O Jogo Teatral no Livro do Diretor (Perspectiva, 2004) entre outros. Fonte: Currículo Lattes certificado pela autora em 20 nov. 2011.

${ }^{11}$ O NCT montou: A vida como ela é, as crônicas de Nelson Rodrigues, 1992 e 2002; Cândido ou o otimismo, o romance de Voltaire, 1993; Tragédias cariocas para rir, contos de vários 
autores, 1996; Correio sentimental de Nelson Rodrigues, coluna de correio sentimental do autor, com o pseudônimo de Myrna, 1999; O menino de paixões de ópera, crônicas autobiográficas de Nelson Rodrigues, 2000. Todos os espetáculos foram dirigidos por Luis Artur Nunes com os atores fundadores, já citados, e outros.

${ }^{12}$ Sou professora responsável pelas disciplinas de Movimento na Escola de Teatro da UNIRIO, atuando principalmente no $1^{\circ}$ e $3^{\circ}$ períodos.

${ }^{13}$ Renato Icarhy da Silveira é diretor teatral e professor do Departamento de Direção da Escola de Teatro da UNIRIO, com Mestrado em andamento na mesma instituição; professor de Interpretação na CAL - Casa das Artes de Laranjeiras. 


\section{Referências}

ABREU, Caio Fernando. Morangos Mofados. São Paulo: Companhia das Letras, 1982.

ABREU, Caio Fernando. Sapatinhos Vermelhos. In: ABREU, Caio Fernando. Os Dragões não Conhecem o Paraíso. São Paulo: Companhia das Letras, 1988. P. 69-80

ALPHONSUS, João. Galinha Cega. In: MORICONI, Ítalo (Org.). Os Cem Melhores Contos Brasileiros do Século. Rio de Janeiro: Objetiva, 2000. P. 85-90

ANDERSEN, Hans Christian. Os Sapatos Vermelhos. In: ANDERSEN, Hans Christian. Contos de Andersen. Rio de Janeiro: Paz e Terra, 1978.

CARRIÈRE, Jean-Claude. O Círculo dos Mentirosos: contos filosóficos do mundo inteiro. São Paulo: Códex, 2004.

DO RIO, João. Melhores Contos de João do Rio. Seleção de Maria Helena Parente Cunha. São Paulo: Global, 2001.

FIGUEIREDO, Luciano (Org.). Ligia Clark - Hélio Oiticica: cartas 1964 -74. Rio de Janeiro: UFRJ, 1998.

GALEANO, Eduardo. O Teatro do Bem e do Mal. Porto Alegre: L\&PM, 2007.

GARCIA, Silvana. Teatro da Militância: a intenção do popular no engajamento político. São Paulo: Perspectiva, 2004.

LOPES NETO, João Simões. Salamanca do Jarau. In: LOPES NETO, João Simões. Lendas do Sul. Porto Alegre: Globo, 1980. P. 33-74.

MANN, Klaus. Mefisto: romance de uma carreira. São Paulo: Estação Liberdade, 2000.

MATIAS, Ligia Borges de. Investigações acerca do Uso da Narrativa no Teatro Contemporâneo. 2009. Dissertação (Mestrado em Artes) - Universidade Estadual Paulista Júlio de Mesquita Filho, São Paulo, 2010.

MÜLLER, Heiner. História de Amor. In: MÜLLER, Heiner. Medeamaterial e Outros Textos. São Paulo: Paz e Terra, 1993. P. 77-84.

PICON-VALLIN, Béatrice. A Arte do Teatro: entre tradição e vanguarda: Meyerhold e a cena contemporânea. Rio de Janeiro: Teatro do Pequeno Gesto/ Letra e Imagem, 2006.

PISCATOR, Erwin. Teatro Político. [S.1.]: Civilização Brasileira: 1968.

SUDERMANN, Hermann. O Guardador de Patos. In: Antologia. Os Mais Belos Contos Burlescos, Irônicos e Sarcásticos. Rio de Janeiro: Vecchi, 1947. P. 61-69.

VILELA, Nereida Fontes; SANTOS, João Celso dos. Leitura Corporal: a linguagem da emoção inscrita no corpo. Belo Horizonte: Núcleo de Terapia Corporal, 2010.

V CONGRESSO DA ASSOCIAÇÃO BRASILEIRA DE PESQUISA E PÓS-GRADUAÇÃO EM ARTES CÊNICAS, 2008, Belo Horizonte. Anais... Belo Horizonte: UFMG, 2008. 
Nara Waldemar Keiserman é professora Adjunta IV na Universidade Federal do Estado do Rio de Janeiro - UNIRIO, atuando na Graduação e no Programa de Pós-Graduação da Escola de Teatro. Possui mestrado em teatro pela Universidade de São Paulo, doutorado em teatro pela UNIRIO e Pós-doutorado na Universidade de Lisboa.

E-mail: narakeiserman@yahoo.com.br

Recebido em novembro de 2012 Aprovado em abril de 2012 